\title{
HUBUNGAN KEBIASAAN SARAPAN DENGAN KADAR GLUKOSA DARAH REMAJA PUTERI (STUDI PENELITIAN DI SMP NEGERI 13 SEMARANG)
}

\author{
Triesa Rizkyta, Tatik Mulyati*) \\ Program Studi Ilmu Gizi Fakultas Kedokteran Universitas Diponegoro \\ Jl.Dr.Sutomo No.18, Semarang, Telp (024) 8453708, Email : gizifk@undip.ac.id
}

\begin{abstract}
Background: Adolescents girl are susceptible having a nutritional problems because of having irregular diet intake and skipping meals especially breakfast and dinner to get an ideal body. If breakfast is consumed at 20-25\% from daily requirement, it can provides fuel for glucose oxidation after 10-12 hour fasting of the time last dinner. For activity in the morning, glucose storage in the body is only sufficient for 2-3 hour activities. Breakfast skippers was more vulnerable having a lower blood glucose as the condition of gastric emptying due to lack of food since dinner time.

Methods: A cross-sectional study with two independent groups. Subjects were calculated with unpaired categoric samples formula and were selected 54 adolescents girl 13-15 years old and divided into breakfast and non-breakfast groups 27 subjects each. Breakfast is defined as the consumption of staple food and dishes since wake up in the morning until 10.00 AM. Data collected were analyzed using Gamma and Somers'd.

Result: Blood glucose among non-breakfast group were low (70.4\%) and breakfast group were enough (62.9\%). The result of this study indicates that breakfast habits has a positive correlation with blood glucose levels with $r=0.603$; $p=0.009 ; R P=1.9$.

Conclusion: There is a correlation between breakfast habits and blood glucose. Non-breakfast group was 1,9 times greater risk of having low blood glucose compared with breakfast group.

Keyword : breakfast; blood glucose; adolescents girl
\end{abstract}

\begin{abstract}
ABSTRAK
LatarBelakang : Remaja puteri rentan mengalami masalah gizi karena memiliki pola makan yang tidak teratur dan sering melewatkan waktu makan terutama sarapan serta makan malam untuk mewujudkan tubuh ideal. Sarapan yang memenuhi 20-25\% dari kebutuhan, berkontribusi dalam menyediakan bahan bakar untuk oksidasi glukosa setelah berpuasa 10-12 jam dari waktu terakhir makan malam, cadangan glukosa dalam tubuh hanya cukup untuk aktivitas 2-3 jam pada pagi hari. Sarapan yang dilewatkan menyebabkan tubuh rentan mengalami penurunan kadar glukosa darah karena keadaan lambung kosong sejak makan malam.

Metode :Penelitian cross-sectional dengan dua kelompok tidak berpasangan. Subjek penelitian dihitung dengan rumus perhitungan sampel kategorik tidak berpasangan dan dipilih 54 remaja puteri berusia 13-15 tahun kemudian dibagi menjadi kelompok sarapan dan tidak sarapan. Sarapan didefinisikan sebagai konsumsi makanan pokok dan lauk pauk sejak bangun tidur hingga pukul 10.00 WIB. Analisis statistik menggunakan uji Gamma dan Somers'd.

Hasil :Kadar glukosa darah pada kelompok tidak sarapan dikategorikan kurang (70.4\%) dan kelompok sarapan dikategorikan cukup (62.9\%). Ada hubungan kebiasaan sarapan dengan kadar glukosa darah $r=0.603 ; p=0.009 ; R P$ $=1.9$.
\end{abstract}

Kesimpulan : Ada hubungan kebiasaan sarapan dengan kadar glukosa darah. Tidak sarapan berisiko 1.9 kali lebih besar memiliki kadar glukosa darah kurang dibandingkan dengan sarapan.

Kata kunci : sarapan; kadar glukosa darah; remaja puteri

\section{PENDAHULUAN}

Usia remaja merupakan sumber daya manusia yang paling potensial untuk mewujudkan tujuan pembangunan nasional. ${ }^{1}$ Menurut World Human Organization (WHO), remaja adalah anak yang mencapai usia 10-19 tahun. Berdasarkan sensus penduduk dari Badan Pusat Statistik (BPS) pada tahun 2010, jumlah remaja usia 10-19 tahun yaitu 44 juta jiwa atau $18,5 \%$ dari total jumlah penduduk 237,6 juta jiwa. ${ }^{2}$

Remaja rentan mengalami masalah gizi karena merupakan masa transisi dari masa kanakkanak menuju masa dewasa dan sangat berpengaruh terhadap pemenuhan kebutuhan zat gizi dan perilaku makan. ${ }^{1}$ Pendapat bahwa tubuh langsing serta tinggi merupakan tubuh yang ideal, menyebabkan remaja terutama remaja puteri berupaya untuk mewujudkan, yaitu dengan memiliki pola makan tidak teratur dan sering melewatkan waktu makan terutama sarapan dan makan malam. ${ }^{3}$ Penelitian observasional di Minnesota dengan subjek 1215 remaja menunjukkan bahwa $16,4 \%$ remaja puteri dan $13 \%$ remaja putera tidak pernah sarapan. ${ }^{4}$ Hasil penelitian observasional di Depok Jawa Barat tahun

\footnotetext{
${ }^{*}$ Penulis Penanggungjawab
} 
2009 menunjukkan bahwa dari 217 subjek sebanyak $41,5 \%$ remaja puteri tidak terbiasa sarapan pagi. ${ }^{5}$

Sarapan dengan menu lengkap, yaitu mengandung karbohidrat, protein, dan lemak serta memenuhi $20-25 \%$ total kebutuhan energi sehari ${ }^{6}$ berkontribusi dalam menyediakan bahan bakar untuk oksidasi glukosa terutama setelah berpuasa selama 10-12 jam dari waktu terakhir makan malam. ${ }^{7}$ Keadaan berpuasa tersebut menyebabkan cadangan glukosa darah dalam tubuh hanya cukup untuk aktivitas 2 sampai 3 jam pada pagi hari. ${ }^{6}$ Oleh karena itu, dibutuhkan pemenuhan kebutuhan energi untuk melakukan aktivitas selanjutnya.

Sarapan yang dilewatkan menyebabkan keadaan lambung kosong sejak makan malam sebelumnya hingga makan siang. ${ }^{8}$ Hal ini menyebabkan tubuh rentan mengalami penurunan kadar glukosa darah atau disebut hipoglikemia. Hipoglikemia mengakibatkan tubuh gemetar, pusing, dan sulit berkonsentrasi. Sulit berkonsentrasi ini menjadi dampak dari kekurangan glukosa yang artinya sama dengan kekurangan sumber energi bagi otak. ${ }^{9}$ Dengan demikian akan berakibat buruk pada kemampuan intelektual dan menyebabkan penurunan prestasi belajar di sekolah. ${ }^{8}$ Kebiasaan tidak sarapan pagi dalam jangka panjang juga akan menyebabkan asupan zat gizi menjadi berkurang dan tidak seimbang sehingga mengganggu proses pertumbuhan. ${ }^{8}$

Berdasarkan Riskesdas 2010, sebanyak $54,4 \%$ remaja dengan rentang usia 13-15 tahun mengonsumsi energi dibawah kebutuhan minimal. Jumlah ini lebih banyak jika dibandingkan dengan anak usia 7-12 tahun yang mengonsumsi energi dibawah kebutuhan minimal yaitu sebanyak 44\%. ${ }^{10}$

Asupan energi yang kurang salah satu penyebab kurangnya status gizi individu. Kekurangan asupan energi dapat diartikan sebagai kekurangan asupan makronutrien, seperti protein, lemak, dan karbohidrat. ${ }^{6}$ Karbohidrat dibutuhkan $60-70 \%$ dari total energi merupakan zat gizi utama yang dipecah menjadi glukosa untuk diserap tubuh dan dimanfaatkan sebagai sumber energi terutama bagi otak. Walaupun berat otak hanya sekitar $2 \%$ dari total berat badan, otak menggunakan $<20 \%$ dari energi tubuh saat istirahat atau tidur malam. ${ }^{6}$

Otak memiliki sedikit simpanan glukosa dan tidak ada simpanan energi lainnya karena otak hanya dapat menggunakan glukosa sebagai sumber energi. ${ }^{6}$ Tanpa penggantian glukosa, otak akan kekurangan glukosa dalam waktu $<10$ menit. $^{6}$ Fungsi otak menjadi terpengaruh secara signifikan apabila kadar glukosa turun hingga menjadi 40 $\mathrm{mg} / \mathrm{dl} .{ }^{6}$ Kadar glukosa yang terlalu rendah dapat mengakibatkan kerusakan otak permanen hingga kematian. ${ }^{6}$ Batas normal kadar glukosa darah yaitu $70-110 \mathrm{mg} / \mathrm{dl} .{ }^{11}$

Konsumsi glukosa yang kurang dapat menyebabkan terjadinya perubahan kadar asetilkolin, insulin, serotonin, glutamat, dan kortisol yang semuanya dapat mempengaruhi fungsi kognitif. ${ }^{7,12}$ Otak memiliki peran salah satunya dalam fungsi kognitif, sehingga apabila terjadi penurunan kadar glukosa dapat mempengaruhi kemampuan kognitif terutama pada remaja yang menyebabkan kesulitan berkonsentrasi dan penurunan daya ingat sehingga mengganggu proses belajar di sekolah. ${ }^{13}$

Penelitian observasional di Australia, menunjukkan bahwa 3.007 subjek berusia 2-18 tahun yang mempunyai kebiasaan sarapan cenderung mendapatkan asupan zat gizi lebih tinggi dan asupan lebih sehat serta memadai. ${ }^{14}$ Penelitian observasional yang dilakukan di Jakarta Timur tahun 2002 menunjukkan bahwa siswa yang sarapan memiliki rerata kadar glukosa $67,97 \pm 29,15$ $\mathrm{mg} / \mathrm{dl}$ lebih tinggi dari siswa yang tidak sarapan yaitu $62,73 \pm 18,29 \mathrm{mg} / \mathrm{dl}^{15}$

Data dari Badan Pusat Statistik tahun 2011 menunjukkan penduduk remaja usia 13-15 tahun di Kota Semarang merupakan penduduk terbanyak ketiga dalam kelompok penduduk usia sekolah. ${ }^{16}$ Penelitian mengenai hubungan kebiasaan sarapan dengan kadar glukosa darah remaja puteri berusia 13-15 tahun belum pernah dilakukan.

Berdasarkan latar belakang tersebut, peneliti ingin meneliti hubungan kebiasaan sarapan dengan kadar glukosa darah remaja puteri dengan studi penelitian dilakukan di SMP Negeri 13 Semarang.

\section{METODE}

Penelitian ini termasuk dalam penelitian bidang gizi masyarakat dengan jenis penelitian observasional dan desain cross-sectional dengan dua kelompok tidak berpasangan yang dilakukan pada bulan Juli 2014 di SMP Negeri 13 Semarang. Populasi target dalam penelitian ini adalah seluruh remaja puteri di Kota Semarang, sedangkan populasi terjangkau adalah remaja puteri di SMP Negeri 13 Semarang.

Perhitungan subjek penelitian menggunakan rumus perhitungan sampel kategorik tidak berpasangan. ${ }^{17}$ Pengambilan subjek dengan metode consecutive sampling yaitu semua subjek yang datang dan memenuhi kriteria pemilihan dimasukkan dalam penelitian sampai jumlah subjek yang diperlukan terpenuhi. Kriteria inklusi antara lain berusia 13-15 tahun, bersedia mengisi informed consent, tidak sedang sakit dan menjalani puasa 
pada saat pengambilan data, tidak mempunyai riwayat keluarga Diabetes Mellitus, dan tidak memiliki aktivitas fisik dengan intensitas sangat aktif. Didapatkan sebanyak 68 remaja puteri memenuhi kriteria inklusi dan diambil 54 sebagai subjek penelitian kemudian dibagi menjadi kelompok sarapan dan tidak sarapan masing-masing 27 subjek.

Variabel terikat (dependent) dalam penelitian ini kadar glukosa darah sewaktu, sedangkan variabel bebas (independent) kebiasaan sarapan dan tidak sarapan. Sarapan didefinisikan sebagai makanan pokok dan lauk pauk yang berlangsung sejak bangun tidur pagi sampai dengan jam 10.00 WIB. Dikategorikan memiliki kebiasaan sarapan bila dalam seminggu melakukan sarapan > 3 kali dan dikatakan tidak memiliki kebiasaan sarapan bila tidak sama sekali atau dalam seminggu melakukan sarapan $\leq 3$ kali dalam seminggu.

Data primer meliputi identitas subjek berupa nama, usia, dan ada/ tidaknya riwayat keluarga Diabetes Mellitus. Pengukuran berat badan dengan timbangan digital kapasitas $120 \mathrm{~kg}$ dan tingkat ketelitian $0,1 \mathrm{~kg}$ dan tinggi badan dengan mikrotoa tingkat ketelitian $0,1 \mathrm{~cm}$. Kadar glukosa darah sewaktu diukur dengan metode GOD PAP (Glucose Oxidase) yang dilakukan oleh petugas Laboratorium Permata Semarang.

Penelitian diawali dengan sosialisasi pada populasi. Peneliti menawarkan kesediaan kepada subjek yang memenuhi kriteria untuk menjadi subjek penelitian. Subjek kemudian dibagi menjadi dua kelompok, yaitu kelompok sarapan dan tidak sarapan. Jika bersedia menjadi subjek penelitian, maka diminta menandatangani lembar informed consent. Selanjutnya dilakukan pengambilan darah subjek pada pukul 10.00 WIB dan pengukuran tinggi badan serta berat badan untuk mengetahui indeks massa tubuh (IMT). Setelah itu pengambilan data asupan zat gizi diperoleh dengan food recall selama 3 hari secara tidak berurutan untuk mengetahui gambaran kebiasaan sarapan dan pola makan subjek.

Status gizi berdasarkan IMT dikategorikan menggunakan klasifikasi IMT menurut World Health Organization (WHO) $2005,{ }^{18}$ yaitu $<17$ $\mathrm{kg} / \mathrm{m}^{2}$ underweight berat, 17,1-18,5 $\mathrm{kg} / \mathrm{m}^{2}$ underweight ringan, $18,6-25 \mathrm{~kg} / \mathrm{m}^{2}$ normal, $25,1-27$ $\mathrm{kg} / \mathrm{m}^{2}$ overweight, dan $>27 \mathrm{~kg} / \mathrm{m}^{2}$ obesitas. Data asupan zat gizi dihitung dengan menggunakan AKG individu dan dikategorikan menjadi kurang $<90 \%$ AKG, baik 90-120\% AKG, dan lebih > 20\% AKG. ${ }^{19}$ Aktivitas fisik dikategorikan berdasarkan kuesioner aktivitas fisik yang diadaptasi dari Commitee Refference Dietary Intake tahun 2005, ${ }^{20}$ yaitu sedentary 1,0-1,39, low active 1,4-1,59, aktif 1,61,89 , dan sangat aktif $>1,9$. Kadar glukosa darah dikategorikan menjadi kurang $<86,4 \mathrm{mg} / \mathrm{dl}$ dan cukup $\geq 86,4 \mathrm{mg} / \mathrm{dl}^{12}$

Data asupan zat gizi dianalisis menggunakan program Nutrisurvey, aktivitas fisik dianalisis secara manual dengan perhitungan skor, dan kadar glukosa darah dianalisis melalui pemeriksaan laboratorium. Pengolahan dan analisis data dilakukan dengan program SPSS (Statistical Package for Social Science) versi 16 for windows.

Karakteristik subjek dianalisis dengan analisis deskriptif. Uji beda Chi Square digunakan untuk melihat perbedaan status gizi dan aktivitas fisik antara kelompok sarapan dan tidak sarapan. Uji korelasi Gamma dan Somers'd digunakan untuk melihat hubungan kebiasaan sarapan dengan kadar glukosa darah.

\section{HASIL PENELITIAN \\ Gambaran Umum Subjek Penelitian}

Tabel 1. Gambaran Umum Subjek Penelitian

\begin{tabular}{|c|c|c|c|c|c|}
\hline \multirow{2}{*}{ Variabel } & \multicolumn{2}{|c|}{ Sarapan } & \multicolumn{2}{|c|}{ Tidak Sarapan } & \multirow{2}{*}{$\mathbf{p}$} \\
\hline & $\mathrm{n}$ & $\%$ & $\mathrm{n}$ & $\%$ & \\
\hline \multicolumn{6}{|l|}{ Status Gizi } \\
\hline Underweight berat & 6 & $22,2 \%$ & 5 & $18,5 \%$ & \multirow{5}{*}{$0.617 *$} \\
\hline Underweight ringan & 11 & $40,8 \%$ & 7 & $25,9 \%$ & \\
\hline Normal & 8 & $29,6 \%$ & 11 & $40,8 \%$ & \\
\hline Overweight & - & - & 1 & $3,7 \%$ & \\
\hline Obesitas & 2 & $7,4 \%$ & 3 & $11,1 \%$ & \\
\hline Total & 27 & $100 \%$ & 27 & $100 \%$ & \\
\hline \multicolumn{6}{|l|}{ Aktivitas Fisik } \\
\hline Sedentary & 26 & $48,1 \%$ & 27 & $50 \%$ & $0.313 *$ \\
\hline Aktif & 1 & $1,9 \%$ & - & - & \\
\hline Total & 27 & $100 \%$ & 27 & $100 \%$ & \\
\hline
\end{tabular}

*Uji Beda Chi Square

Status gizi subjek pada kelompok tidak sarapan sebagian besar dikategorikan normal kelompok sarapan underweight berat dan ringan sebanyak 17 orang (63\%). Aktivitas fisik seluruh sebanyak 11 orang $(40,8 \%)$, sedangkan pada subjek pada kelompok tidak sarapan dikategorikan 
sedentary 27 orang (100\%), sedangkan pada kelompok sarapan yang subjek dikategorikan

memiliki aktivitas fisik sedentary sebanyak 26 orang $(96,3 \%)$.

Tabel 2. Kategori Asupan Zat Gizi

\begin{tabular}{lcccc}
\hline \multirow{2}{*}{ Variabel } & \multicolumn{2}{c}{ Sarapan } & \multicolumn{2}{c}{ Tidak Sarapan } \\
\cline { 2 - 5 } & $\mathrm{n}$ & $\%$ & $\mathrm{n}$ & $\%$ \\
\hline $\begin{array}{l}\text { Asupan Zat Gizi } \\
\text { Asupan Energi }\end{array} \quad$ & & & \\
$\quad$ Kurang & 7 & $25.9 \%$ & 25 & $92.6 \%$ \\
$\quad$ Baik & 20 & $74.1 \%$ & 2 & $7.4 \%$ \\
$\quad$ Lebih & - & - & - & - \\
\hline Total & 27 & $100 \%$ & 27 & $100 \%$ \\
\hline Asupan Karbohidrat & & & & \\
$\quad$ Kurang & 12 & $44.4 \%$ & 25 & $92.6 \%$ \\
$\quad$ Baik & 14 & $51.9 \%$ & 2 & $7.4 \%$ \\
$\quad$ Lebih & 1 & $3.7 \%$ & - & \\
\hline Total & 27 & $100 \%$ & 27 & $100 \%$ \\
\hline Asupan Protein & & & & \\
$\quad$ Kurang & 13 & $48.1 \%$ & 24 & $88,9 \%$ \\
$\quad$ Baik & 13 & $48.1 \%$ & 3 & $11.1 \%$ \\
$\quad$ Lebih & 1 & $3.8 \%$ & - & - \\
\hline Total & 27 & $100 \%$ & 27 & $100 \%$ \\
\hline
\end{tabular}

Berdasarkan tabel 2, diketahui bahwa sebagian besar subjek pada kelompok sarapan dikategorikan memiliki asupan energi baik sebanyak 20 orang $(74,1 \%)$ dan pada kelompok tidak sarapan dikategorikan memiliki asupan energi kurang sebanyak 25 orang $(92,6 \%)$. Kategori asupan karbohidrat pada sebagian besar subjek kelompok tidak sarapan adalah kurang sebanyak 25 orang $(92,6 \%)$ dan subjek pada kelompok sarapan adalah baik sebanyak 14 orang $(51,9 \%)$. Sebagian besar subjek pada kelompok tidak sarapan dikategorikan dalam asupan protein kurang yaitu sebanyak 24 orang $(88,9 \%)$ dan pada kelompok sarapan dikategorikan dalam asupan protein baik sebanyak 13 orang $(48,1 \%)$.

Tabel 3. Kategori Kadar Glukosa Darah Sewaktu

\begin{tabular}{ccccccc}
\hline \multirow{2}{*}{ Kelompok } & \multicolumn{2}{c}{ Kategori Kadar Glukosa Darah Sewaktu } & \multirow{2}{*}{ Total } & \multirow{2}{*}{$\mathbf{r}$} & \multirow{2}{*}{$\mathbf{p}$} \\
\cline { 2 - 4 } & Kurang & Cukup & & & \multirow{2}{*}{$0.009 *$} \\
\hline Tidak sarapan & 19 & 8 & 27 & $0.603 *$ & \multirow{2}{*}{0.009} \\
Sarapan & 10 & 25 & 54 & & \\
\hline Total & 29 & & &
\end{tabular}

*Uji Korelasi Gamma

Tabel 3 menunjukkan sebagian besar subjek pada kelompok tidak sarapan memiliki kadar glukosa kurang sebanyak 19 orang $(70,37 \%)$ dan pada kelompok sarapan memiliki kadar glukosa cukup sebanyak 17 orang $(62,96 \%)$.

\section{Hubungan Kebiasaan Sarapan dengan Kadar} Glukosa Darah

Hasil uji korelasi Gamma dan Somers'd menunjukkan bahwa ada hubungan kebiasaan sarapan dengan kadar glukosa darah dengan koefisien relasi 0,603 dan nilai p 0,009 ( $p<0,05)$. Koefisien relasi 0,603 menunjukkan hubungan yang kuat.

Rasio prevalens menunjukkan perbandingan antara jumlah subjek pada kelompok sarapan dan tidak sarapan yang mempunyai kadar glukosa darah kurang. Perhitungan rasio prevalens didapatkan nilai 1,9 . Nilai rasio prevalens lebih dari
1,0 menunjukkan bahwa variabel tersebut merupakan fatkor risiko untuk terjadinya efek. Artinya, subjek yang tidak memiliki kebiasaan sarapan berisiko 1,9 kali lebih besar mempunyai kadar glukosa darah kurang dibandingkan dengan subjek yang memiliki kebiasaan sarapan.

\section{PEMBAHASAN}

Subjek pada penelitian ini adalah remaja puteri usia 13-15 tahun di SMP Negeri 13 Semarang yang berjumlah 27 orang pada masing-masing kelompok sarapan dan tidak sarapan serta memenuhi kriteria inklusi. Remaja berusia 13-15 tahun membutuhkan karbohidrat, protein, lemak, vitamin, dan mineral yang lebih tinggi dibandingkan dengan kelompok usia dewasa karena pada usia remaja dibutuhkan zat gizi yang cukup 
untuk pertumbuhan, energi, dan mempertahankan fungsi tubuh. ${ }^{21}$

Status gizi adalah gambaran kesehatan tubuh individu yang merupakan hasil dari riwayat kebiasaan asupan zat gizi baik dari masa lalu maupun asupan zat gizi saat ini. ${ }^{22}$ Sebagian besar subjek pada kelompok sarapan (63\%) memiliki status gizi underweight ringan dan berat. Sedangkan subjek pada kelompok tidak sarapan sebagian besar (40,8\%) memiliki status gizi normal. Hal ini disebabkan karena subjek pada kelompok tidak sarapan memiliki aktivitas yang lebih rendah dibandingkan dengan subjek pada kelompok sarapan.

Aktivitas fisik merupakan gerakan tubuh yang dihasilkan oleh otot rangka yang membutuhkan pengeluaran energi. ${ }^{23}$ Subjek penelitian pada kelompok tidak sarapan seluruhnya dikategorikan dalam aktivitas sedentary. Aktivitas lebih banyak digunakan untuk duduk menonton televisi, bermain komputer dan belajar di sekolah, serta berjalan santai pada jarak dekat. Aktivitas seperti ini dapat membakar sekitar 80-160 kkal/ jam, ${ }^{24}$ sehingga apabila asupan zat gizi tidak memenuhi kebutuhan tubuh akan terasa lemas dan kurang bersemangat untuk melakukan aktivitas.

Asupan energi sebagian besar subjek pada kelompok sarapan dikategorikan dalam asupan energi baik $(74,1 \%)$, sedangkan pada kelompok tidak sarapan dikategorikan dalam asupan energi kurang (92,6\%). Asupan karbohidrat pada kelompok sarapan sebagian besar juga dikategorikan baik $(51,9 \%)$, sedangkan kelompok tidak sarapan dikategorikan kurang (92,6\%). Asupan protein pada kelompok sarapan sebagian dikategorikan baik $(48,1 \%)$ dan sebagian lagi dikategorikan kurang $(48,1 \%)$. Sedangkan pada kelompok tidak sarapan sebagian besar dikategorikan dalam asupan protein kurang $(88,9 \%)$.

Asupan kurang pada kelompok tidak sarapan mengakibatkan kurangnya energi yang akan digunakan tubuh untuk beraktivitas. Sehingga subjek pada kelompok tidak sarapan cenderung tidak banyak beraktivitas. Berbeda halnya dengan dengan subjek pada kelompok sarapan yang mendapatkan cukup energi untuk beraktivitas lebih banyak. Hal inilah yang menjadi alasan sebagian besar status gizi subjek pada kelompok sarapan adalah underweight dan kelompok tidak sarapan adalah normal.

Kadar glukosa darah sebagian besar subjek pada kelompok tidak sarapan dikategorikan kurang $(70,4 \%)$, sedangkan kelompok sarapan dikategorikan cukup (62,9\%). Berdasarkan hasil uji korelasi Gamma dan Somers'd, terdapat hubungan yang signifikan antara kebiasaan sarapan dengan kadar glukosa darah dengan koefisien relasi 0,603 dan nilai p 0,009. Hasil ini menunjukkan bahwa kadar glukosa darah salah satunya dipengaruhi oleh sarapan. Hal ini disebabkan karena sarapan berperan dalam membantu memenuhi kebutuhan zat-zat gizi yang selanjutnya akan digunakan sebagai bahan utama dalam pembentukan glukosa di dalam darah..$^{25}$

Rasio prevalens menunjukkan perbandingan antara jumlah subjek pada kelompok sarapan dan tidak sarapan yang mempunyai kadar glukosa darah kurang. ${ }^{26}$ Perhitungan rasio prevalens didapatkan nilai 1,9 . Subjek yang tidak memiliki kebiasaan sarapan berisiko 1,9 kali lebih besar mempunyai kadar glukosa darah kurang dibandingkan dengan subjek yang memiliki kebiasaan sarapan.

Sarapan merupakan salah satu waktu makan yang dapat menyumbang energi pada total kebutuhan sehari. Apabila sarapan dilewatkan, maka total kebutuhan energi sehari tidak dapat terpenuhi. Energi dibutuhkan tubuh untuk berlangsungnya proses fisiologis, seperti kontraksi otot, pembentukan dan penghantaran impuls saraf, sekresi kelenjar, dan berbagai reaksi sintesis dan degradasi, serta untuk memelihara fungsi dasar tubuh atau disebut metabolisme basal. Energi yang digunakan dalam aktivitas tubuh tersebut berasal dari pemecahan molekul glukosa yang merupakan hasil dari pencernaan karbohidrat. ${ }^{27}$

Sarapan yang memenuhi 20-25\% kebutuhan zat gizi sehari berkontribusi dalam menyediakan karbohidrat yang akan digunakan sebagai bahan utama pembentukan kadar glukosa darah setelah berpuasa selama 10-12 jam dari waktu terakhir makan malam. ${ }^{28}$ Sarapan dibutuhkan untuk mempertahankan ketersediaan energi yang digunakan untuk jam pertama melakukan aktivitas.

Melewatkan sarapan dapat mengakibatkan tubuh tidak mempunyai cukup energi untuk beraktivitas terutama pada proses belajar. ${ }^{29} \mathrm{Hal}$ ini disebabkan karena pada malam hari dalam tubuh tetap berlangsung proses oksidasi guna menghasilkan energi untuk menggerakkan jantung, paru-paru, dan otot-otot tubuh lainnya. Oleh karena itu, glukosa darah berada pada level terendah pada pagi hari sebelum individu mengonsumsi makanan. ${ }^{29}$ Sehingga, sarapan yang dilewatkan akan menyebabkan persediaan glukosa untuk otak tidak terpenuhi karena cadangan glukosa menurun dalam waktu kurang lebih 18 jam bila tidak ada asupan energi terutama karbohidrat. ${ }^{25}$ 
Penelitian observasional yang dilakukan di Jakarta Timur tahun 2002 menunjukkan bahwa subjek yang sarapan memiliki rerata kadar glukosa $67,97 \pm 29,15 \mathrm{mg} / \mathrm{dl}$ lebih tinggi dari siswa yang tidak sarapan yaitu $62,73 \pm 18,29 \mathrm{mg} / \mathrm{dl} .{ }^{15}$ Proporsi subjek sarapan yang memiliki tingkat konsentrasi tinggi lebih besar dibandingkan dengan subjek tidak sarapan..$^{15}$

Subjek pada kelompok sarapan lebih banyak mengonsumsi makanan sumber karbohidrat seperti nasi dan roti pada saat sarapan. Karbohidrat merupakan sumber energi yang utama bagi sistem saraf dan sel darah merah. ${ }^{25}$ Fungsi utama karbohidrat yang dapat dicerna bagi manusia adalah menyediakan energi untuk sel, termasuk sel otak yang kerjanya tergantung pada suplai karbohidrat berupa glukosa. ${ }^{30}$ Sehingga, sarapan yang baik kualitas dan kuantitasnya dapat menyediakan makronutrien salah satunya yaitu karbohidrat yang digunakan untuk mempertahankan kadar glukosa darah dan menyediakan energi untuk otak.

\section{SIMPULAN}

Kadar glukosa darah kurang sebagian besar terdapat pada kelompok tidak sarapan $(70,4 \%)$ dan kadar glukosa darah cukup sebagian besar pada kelompok sarapan $(62,9 \%)$. Terdapat hubungan yang signifikan antara kebiasaan sarapan dengan kadar glukosa darah remaja puteri dengan koefisien relasi 0,603 dan nilai $\mathrm{p} 0,009$. Rasio prevalens 1,9 menunjukkan subjek yang tidak memiliki kebiasaan sarapan berisiko 1,9 kali lebih besar mempunyai kadar glukosa darah kurang dibandingkan dengan subjek yang memiliki kebiasaan sarapan.

\section{SARAN}

1. Pemberian edukasi kepada penyedia makanan remaja tentang sarapan yang baik adalah yang mengandung $20-25 \%$ energi dari total kebutuhan sehari, seperti sandwich, sereal siap saji yang dihidangkan dengan susu.

2. Penelitian lebih lanjut mengenai hubungan total asupan energi dan konsentrasi belajar dengan kadar glukosa darah.

\section{DAFTAR PUSTAKA}

1. Departemen Kesehatan RI. Kesehatan Remaja dan Solusinya. Salemba Medika: Jakarta; 2010.

2. Badan Pusat Statistik (BPS). Laporan Sensus Penduduk Indonesia. Badan Pusat Statistik. Jakarta; 2010.

3. Widianti, N. Hubungan antara Body Image dan Perilaku Makan dengan Status Gizi Remaja Putri di SMA Theresiana Semarang. Fakultas Kedokteran Universitas Diponegoro; 2012.
4. Timlin, MT, Mark AP, Mary Story, and Dianne N Sztainer. Breakfast Eating and Weight Change in a 5-year Prospective Analysis of Adolescent: Project EAT (Eating Among Teens). Pediatrics 2008; 121, e638.

5. Hermina. Faktor-faktor yang Mempengaruhi Kebiasaan Makan Pagi pada Remaja Putri di Sekolah Menengah Pertama (SMP). PGM 2009; 32(2): 94-100.

6. Arijanto, A, dkk. Hubungan antara Kebiasaan Sarapan dengan Prestasi Belajar yang Dicapai dalam Bidang IPA, IPS, Olahraga, Total Nilai dan Daya Ingat pada Siswa Kelas VI SDN Pranti Kecamatan Sedati Kabupaten Sidoarjo. Fakultas Kedokteran Universitas Wijaya Kusuma Surabaya. 2008;11-13.

7. Hoyland A, Louise Dye, and Clare L. Lawton. A Systematic Review of the Effects of Breakfast on the Cognitive Performance of Children and Adolescents. Nutrition Research Review's 22. 2009; 220-243.

8. Khomsan, A. Pangan dan Gizi Kesehatan. Jurusan Gizi Masyarakat Fakultas Pertanian Institut Pertanian Bogor; 2002.

9. Brandt, M. Chapter 5: Endocrine Regulation of Glucose Metabolism. Rose Hulman Institute of Technology; 2005: 330.

10. Badan Penelitian dan Pengembangan Kesehatan Republik Indonesia. Laporan Riskesdas 2010. Jakarta; 2010.

11. PERKENI. Konsensus Pengelolaan Diabetes Mellitus Tipe 2 di Indonesia 2002. Jakarta; 2002.

12. Benton, D and Pearl Y Parker. Breakfast, Blood Glucose, and Cognition. American Journal of Clinical Nutrition 1998; 67: 772S-8S. USA.

13. Adolphus K, Clare L. Lawton, and Louise Dye. The Effects of Breakfast on Behavior and Academic Performance in Children and Adolescents. Frontiers on Human Neuroscience 2013; 7: 425.

14. Williams, P. Breakfast and the Diets of Australian Children and Adolescents: an Analysis of Data from the 1995 National Nutrition Survey. Int J Food Sci Nutr. 2007; 58:201-216.

15. Faridi, A. 2002. Hubungan Sarapan dengan Kadar Glukosa Darah dan Konsentrasi Belajar pada Siswa Sekolah Dasar. Bogor: Fakultas Pertanian Institut Pertanian Bogor; 2002.

16. Badan Pusat Statistik Penduduk Usia Sekolah Menurut Kabupaten/Kota dan Kelompok Umur. Diakses

dari http://jateng.bps.go.id/index.php?option=com_cont ent\&view=article\&id=619:04-01$01 \&$ catid $=47$ : sosial-2012\&Itemid $=88$ pada 22 Agustus 2014.

17. Dahlan, M. Sopiyudin. Besar Sampel dan Cara Pengambilan Sampel dalam Penelitian Kedokteran dan Kesehatan Edisi 3. Jakarta: Penerbit Salemba Medika; 2013: 46.

18. Keputusan Menteri Kesehatan Republik Indonesia Nomor: 1995/Menkes/SK/XII/2010. Standar 
Antropometri Penilaian Status Gizi Anak. Jakarta: Direktorat Bina Gizi; 2011.

19. Anggraeni, AC. Asuhan Gizi; Nutritional Care Process. Yogyakarta: Graha Ilmu; 2012.

20. Sharon, RR, Kathryn Pinna, dan Ellie Whitney. Understanding Clinical Nutrition, 8th Edition. Belmont: Wadsworth Cengage Learning; 2009:F-1.

21. Papalia, D E., Olds, S., dan Ruth D. Feldman. Human Development. $8^{\text {th }}$ ed. Boston: McGrawHill; 2001:212.

22. Riyadi. Metode Penilaian Status Gizi secara Antropometri. Diktat Program Studi Gizi Masyarakat dan Sumberdaya Keluarga. Bogor: Fakultas Pertanian, Institut Pertanian Bogor; 2001.

23. Matthys, et al. Breakfast habits affect overall nutrient profiles in adolescents. Public Health Nutrition 2007; 10(4): 413-421.

24. Agoes, D dan Maria Poppy. Mencegah dan Mengatasi Kegemukan pada Balita. Jakarta: Puspa Swara; 2003.

25. Wardlaw, GM., Jeffry SH., Robert AD. Perspective in Nutrition. $6^{\text {th }}$ ed. Boston: McGraw-Hill 2004; 137.

26. Sudigdo, $\mathrm{S}$ dan Sofyan Ismael. Dasar-dasar Metodologi Penelitian Klinis, Edisi Ke-4. Jakarta: Sagung Seto; 2011:130-137.

27. Sloan E, Veldman J. Anatomi dan Fisiologi. Edisi 1. Jakarta: EGC kedokteran; 2004:299.

28. Ni Luh Putu YSC dan Lilis W. Hubungan Kalori Sarapan dengan Kemampuan Konsentrasi Anak Usia Sekolah di SD Negeri 3 Canggu Tahun 2012. Fakultas Kedokteran Universitas Udayana, Bali; 2012.

29. Henrikson JE and Bech-Nielsen H. Blood Glucose Levels 2009. Available from http://www.netdoctor.co.uk diakses pada 24 Agustus 2014.

30. Gallagher, ML. The Nutrients and Their Metabolism. In: Mahan LK, Stump. Krause's food and nutrition therapy. $12^{\text {th }}$ ed. Kanada: Elsevier; 2008:67. 